\title{
Practitioner research in libraries: a cross-sectoral comparison
}

\author{
Sarah McNicol
}

\section{Author}

Sarah McNicol is a Research Fellow at evidence base: research and evaluation, University of Central England (UCE) Library Services.

Email:Sarah.McNicol@uce.ac.uk

\begin{abstract}
Even when research conducted in public library authorities does not have a major impact on policy, it can be crucial for service development. In Spring 2003, the Centre for Information Research (CIRT) at the University of Central England carried out a series of surveys of public, academic, health, school and special libraries in the British Isles in order to obtain up-to-date information about the research issues of particular interest to staff. This indicated that there is significant interest in research, even among those librarians who are not heavily involved in research activity personally. There were a number of common themes which cut across the different library sectors, including ICT, user needs, accommodation, collections, funding, staffing and co-operation. This suggests that, while sector-specific research is necessary in some areas, in others, cross-sectoral research may help library staff to address the common problems they all face.
\end{abstract}

\section{Introduction}

Library and information science research is often regarded as an activity which is important to academics and policymakers, but of little or no immediate relevance to library practitioners. However, research can serve a number of practical purposes, including: informing practice; planning future developments; raising the profile of libraries; and contributing to knowledge. It can help staff at all levels to improve and develop services.

Even though research conducted in public library authorities may not have a major impact on policy, it is crucial for service development. When Goodall sampled twenty public library authorities and asked them to identify the key issues for research activity, she found that, while many did place a high value on research, they did not feel very involved in research activity in the sector. She reported that the role of the practitioner-researcher is often not recognised or highly valued. In addition to a lack of research skills, they face a plethora of additional barriers including: lack of time; lack of resources; lack of support; pressure of other work; the low priority awarded to research activities; lack of confidence; and lack of motivation or incentive (Goodall, 1998).

\section{Methodology}

In Spring 2003, the Centre for Information Research (CIRT) at the University of Central England carried out a series of surveys of public, academic, health, school and special libraries in the British Isles in order to obtain up-to-date information about the research issues of particular interest to staff. It was hoped that 
this information would help to identify future trends and assist in further improving the links between research and practice.

For the purposes of this survey, research included work conducted both in-house and externally funded. Examples of the types of activities which might be considered as research included demonstrator or pilot projects, user surveys, feasibility studies, evaluations, action research projects and involvement in a research project as a case study, research partner or lead institution.

Between March and May 2003, questionnaires were sent to librarians in all public library authorities, academic libraries (including special collections), health libraries and special libraries in England, Wales, Scotland, Northern Ireland and the Republic of Ireland. In addition, a sample of nine local education authorities was chosen and questionnaires sent to the librarians in all state and independent schools within these.

In each survey, librarians were asked for details of:

- research the library had been involved in or had carried out during the previous two years

- the use made of the findings of this or any other research to improve the library services

- research planned for the next twelve months

- $\quad$ areas in which further research is needed and reasons why this was felt to be important

- factors which might encourage the library service to have greater involvement in research.

[See the appendix for a generic version of the questionnaire.]

In each case librarians were given approximately three weeks to reply. Table 1 shows the number of responses received for each sector.

\begin{tabular}{|l|l|}
\hline Library sector & $\begin{array}{l}\text { Number of } \\
\text { responses }\end{array}$ \\
\hline Academic libraries & 62 \\
\hline Health libraries & 83 \\
\hline Public libraries & 78 \\
\hline School libraries & 63 \\
\hline Special libraries & 48 \\
\hline TOTAL & 334 \\
\hline
\end{tabular}

Table 1: Number of responses by library sector

It was not possible to determine the response rate in all cases because mailing details for some sectors were supplied in a single batch. However, the response rate for school libraries was $19.5 \%$ and for health 
libraries it was $12.5 \%$. It was also calculated that $21 \%$ of public library authorities responded as did approximately one-quarter of Higher Educational Institutions (HEIs).

\section{Previous research}

Table 2 indicates the numbers and percentages of respondents from each sector who had been involved in research during the previous two years.

\begin{tabular}{|l|l|l|}
\hline Library sector & $\begin{array}{l}\text { Number involved in } \\
\text { previous research }\end{array}$ & Percentage of respondents \\
\hline Academic libraries & 39 & $63 \%$ \\
\hline Health libraries & 37 & $47 \%$ \\
\hline Public libraries & 52 & $67 \%$ \\
\hline School libraries & 21 & $33 \%$ \\
\hline Special libraries & 24 & $50 \%$ \\
\hline TOTAL & 173 & $52 \%$ \\
\hline
\end{tabular}

Table 2: Number of libraries involved in research during the previous two years

Overall, just over half the respondents reported involvement in some form of research. However, this varied from sector to sector, with the lowest level of involvement being reported amongst school librarians and the highest in public libraries. The scale of organisation appeared to have an impact on the likelihood of carrying out research as academic and public libraries were most likely to be involved, while in smaller scale special, health and school libraries, research activity was more limited.

In all library sectors, user surveys were the most frequently mentioned form of research and this may, in fact, have been under-reported as not all libraries considered it to be 'true research'. In public libraries, the standard CIPFA PLUS methodology was commonly adopted, although some authorities had devised their own user surveys or used other devices such as citizens' panels. These often focused on a particular issue such as opening hours. In other sectors, it was common practice for individual libraries to design their own user surveys.

In special libraries, scoping and pilot projects were mentioned by a number of respondents. Public and academic libraries also commonly participated in pilot projects. Other frequently mentioned types of research included student projects, research by library members; case studies and market research. Libraries from all sectors reported involvement in local and national surveys.

Unlike other sectors, the majority of research carried out in school libraries took the form of externally funded projects. However, one-third of academic libraries had been involved in externally funded projects; these were often on a large scale and involved a number of partners. Public libraries also often worked with partners including other council departments, universities, EU partners, other library authorities and consultants.

The topics researched varied depending on the specific concerns of the sector. The most common subjects among public librarians were: opening hours, the People's Network, lifelong learning, mobile libraries and social inclusion. In health libraries, research into journal usage, use of inter-library loans, the information needs of particular groups and information skills training were some of the areas 
mentioned. Academic libraries had investigated use of specific services such as periodicals, postal loans and electronic services. The more limited involvement in research in school libraries and the diverse interests of special libraries meant it was less easy to identify key issues in the same way for these sectors.

\section{Use of research}

Sometimes, respondents were unable to comment on the use of research findings because projects were ongoing or results had not yet been analysed. On other occasions, the availability of funding limited the implementation of research findings.

Among those librarians who identified ways in which research findings had been used, the most commonly stated were:

- To inform service planning and strategic development e.g. Best Value review

- To devise new approaches and plan new services: facilities for ethnic minority communities, lifelong learning facilities, a new complaints system, and an inter-site book request service are just a few of many examples

- To refine existing services and make operational changes: extended opening hours was a common example. Other respondents mentioned signage and guiding, staffing alternations, new charges and stock purchase

- To improve effectiveness of the library service

- Benchmarking exercises

- To identify staff training needs

- Marketing, publicity and awareness raising

- To plan new library accommodation

- To support funding applications for increased resources or staffing and to support pleas for greater investment in libraries generally

- Reporting to committees or management teams

- To demonstrate the value of libraries to government, funders and others

- To identify the need for further research in a particular area and suggest an area in which a service might be piloted

- General discussion and development of a research ethos.

It was noticeable that very few librarians made use of research other than that which they had been directly involved in. However, school librarians proved to be an exception to this. It was also interesting to note that some public libraries appeared to make greater efforts to disseminate research findings than was the case in other sectors. This might be dissemination to fellow professionals, but also to users and research participants. 


\section{Future research}

Table 3 indicates the number and percentage of questionnaire respondents who planned to carry out research during the next twelve months.

\begin{tabular}{|l|l|l|}
\hline Library sector & $\begin{array}{l}\text { Number planning } \\
\text { involvement in future } \\
\text { research }\end{array}$ & Percentage of respondents \\
\hline Academic libraries & 32 & $52 \%$ \\
\hline Health libraries & 39 & $55 \%$ \\
\hline Public libraries & 50 & $64 \%$ \\
\hline School libraries & 18 & $28 \%$ \\
\hline Special libraries & 20 & $42 \%$ \\
\hline TOTAL & 127 & $38 \%$ \\
\hline
\end{tabular}

Table 3: Number of libraries involved in research during the next twelve months

In each sector, the number of librarians who said they intended to be involved in research during the next twelve months was marginally lower than the number which had been involved in research in the past. Again, public libraries were most likely to have plans, while school libraries were least likely to do so.

The most commonly mentioned form of future research was user surveys; this might be either the repetition of previous surveys to identify change over time or new surveys, perhaps focused on a particular aspect of library provision.

The areas in which librarians planned to carry out research varied between sectors. For instance, in special libraries, the focus of much future research was on electronic resources. A number of health libraries had planned to undertake projects in clinical librarianship. Public libraries suggested a number of innovative methods for future research including: demographic profiling, a mystery shopper exercise and a community audit.

\section{Areas for further research}

In special libraries, the links between library research and the needs of the parent organisation were more explicit than was the case in other sectors. However, to some extent, it could be claimed that this was also true of school libraries, where the main focus was on learning and reading. Admittedly, other sectors, in particular, public libraries have a much wider remit and may not be able to focus on specific issues in such depth.

School librarians were similarly keen to link with the aims of the organisation in which they were based, for example, by research investigating the links between the level of library use and pupils' attainment. Academic librarians, too, were aware of the need to focus library activities on teaching and learning, in particular, information literacy and the contribution to student success. In health libraries, this idea transferred into the need to investigate the impact of library use on clinical practice. Public libraries referred more generally to the need to demonstrate links between the work of libraries and broader political agendas and to demonstrate the social and economic impact of library services. 
ICT was the most common area mentioned in terms of the need for further research across all library sectors. However, the precise areas of interest varied depending on the sector as follows:

- Academic libraries: supporting teaching and learning, cost-effectiveness, access, licensing and staff skills

- Health libraries: ICT skills, print and electronic journals, cost-effectiveness, non-use of electronic resources and impact of electronic resources on library use

- Public libraries: future planning and sustainability of the People's Network and the impact on more general use of libraries

- School libraries: the links between books and computers and the need to combine research tools

- Special libraries: archiving, licensing, relationship between print and electronic resources, funding, user resistance and staff skills

Of course, all libraries were concerned about issues relating to their users. User needs was an area of research mentioned by a number of staff from special and school libraries. In a similar way, public and academic librarians referred to the need for user surveys. In some cases, this was related to the need for research examining the particular needs of defined user groups such as various professional groups using health libraries or socially excluded groups in public libraries. Non-users and lapsed users were also an issue of concern to librarians across the domain; this was often linked to declining usage. Public librarians in particular referred to the need to attract new audiences. User behaviour was another topic which featured in the responses from different sectors.

The issue of social inclusion was an important one generally for public libraries and this can be compared with the widening participation and access agenda which has significance for research in academic libraries. Marketing and publicity was another common concern, especially among librarians from those sectors with less of a 'captive audience', i.e. special, public, health libraries.

Academic and school libraries were not the only sectors concerned with the role of libraries in learning, this was also a concern for public librarians, especially in relation to literacy, information skills and other basic skills. Research relating to reading promotion and reader development was mentioned by both public and school librarians. Among health librarians, there was concern about the effectiveness of information skills training methods.

Unsurprisingly, issues relating to library collections commonly featured. Special, academic and public librarians all referred to collection or stock management.

Library networking and collaboration was mentioned by librarians from all sectors, especially in relation to resource sharing and cost-effectiveness. As well as intra-sectoral collaboration, there was a growing interest in cross-sectoral initiatives, for instance, health libraries referred to co-operation and resourcesharing with public and academic libraries and special librarians to the relationship between academic, national and special libraries.

The exact nature of the librarian's role was a key concern across the domain, although naturally, the precise focus varied between sectors. For example, in school libraries, the librarian's role in teaching information skills and the relationship between the role of the librarians and that of other staff was 
highlighted through numerous references to the need to work with teaching staff within the school. While among health librarians, clinical librarianship and the role of library staff in assisting with information searches were two important issues.

Librarians from all sectors were concerned about general staffing issues such as pay and status, staff training and skills, specialisation, recruitment and retention, and succession planning.

Funding was another issue of concern to all libraries. Public librarians specifically referred to income generation, the impact of fees, consortium purchasing and the effects of short-term funding, while licensing agreements were a key issue for academic libraries.

Library buildings were also an issue which spanned various library sectors. Although, again, the precise nature of research required varied by sector. While public and academic librarians were concerned about the general library environment and the siting of libraries, school librarians were more interested in the need for a dedicated library which was not used for other purposes.

There were, of course, certain issues which were of particular interest to certain sectors, for instance, school librarians mentioned research into homework clubs and health librarians were interested in work relating to library accreditation. Accessibility and enquiry services were important issues for staff in special libraries.

\section{Barriers to research}

The graph below indicates the main barriers which prevented libraries having greater involvement in research.

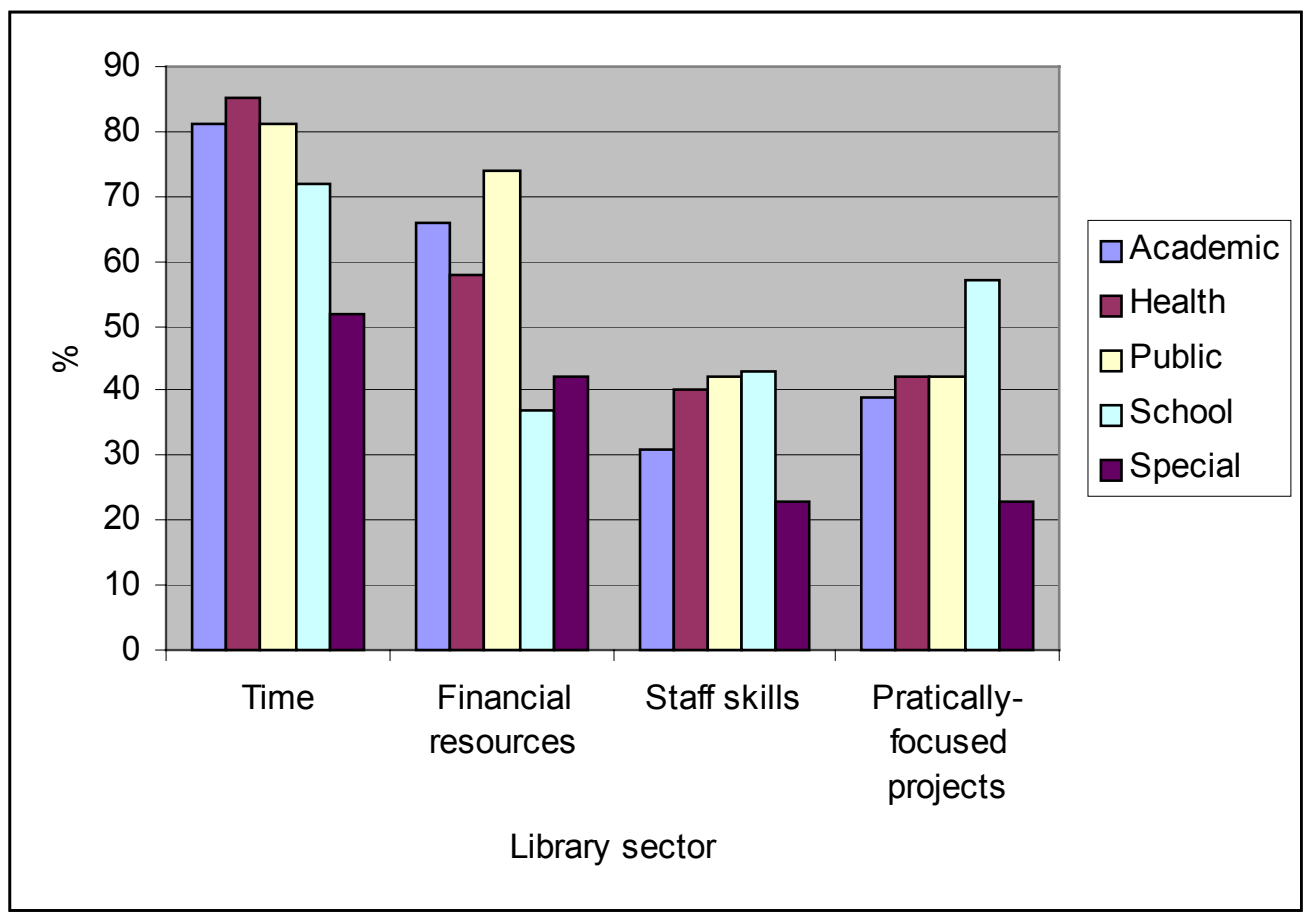

Figure 1: Barriers to involvement in research

In libraries across all sectors, time was identified as the main barrier to further involvement in research. More than four-fifths of librarians in the public, health and academic sectors thought that lack of time was a problem. However, this was seen as much less of a difficulty for librarians in special libraries than it 
was elsewhere. In all sectors except school libraries, a lack of financial resources was the next most frequently cited barrier. This presented the greatest problems in public libraries. Staff skills and a lack of practically focused projects were ranked more or less equally in terms of the percentage of librarians identifying them as barriers to research in health, public and academic libraries. However, in school, and to some extent academic, libraries a lack of practically-focused projects was seen as a much greater problem than it was by librarians from other sectors.

Several librarians mentioned additional factors such as isolation, greater support from senior managers, research which fitted more closely with the objectives of the service and the need for more staff to allow them to carry out research.

\section{Conclusion}

Around half the libraries from all sectors responding to these surveys had been involved in some form of research during the previous two years and only slightly fewer had plans for research during the coming year. Research activity was greatest in academic and public libraries. However, there was evidence of significant interest in research, even among those librarians who have not been heavily involved in research activity. In school libraries in particular, the general impression was that, although research was viewed as an add-on, rather than a core service staff were clearly aware of the importance of research for the sector as a whole. The major barriers which prevent librarians having greater involvement in research are lack of time and lack of money.

User surveys were the most common form of research in all libraries, but across the five sectors, a wide range of topics and research methods were reported. Research findings were put to a wide variety of uses by library staff. However, in general, it would appear that research is mainly used by those libraries directly involved in it. Information about research, which might be helpful to others is not being widely disseminated and implemented.

Areas where it was believed that further research was needed depended, to some extent, on the sector and the circumstances of the library. However, there were a number of common themes, such as ICT, user needs, accommodation, collections, funding, staffing and co-operation. These suggest that, while sectorspecific research is necessary in some areas, in others, cross-sectoral research may help library staff to address the common problems they all face.

\section{Reference}

Goodall, Deborah (1998), “Public library research”, Public Library Journal 13 (4), 49-55.

\section{WORD COUNT: 3116}

